\title{
Penyuluhan Seni Gamelan Dukuh Kadireso
}

\author{
Setyawan Jayantoro \\ Jurusan Karawitan, Fakultas Seni Pertunjukan \\ Institut Seni Indonesia Yogyakarta \\ Jalan Parangtritis Km 6,5 Yogyakarta \\ E-mail: setyawanjayatoro@isi.ac.id
}




\begin{abstract}
Abstrak
Berawal dari pelaksanaan KKN, penulis menjumpai dan merintis terbentuknya kelompok gamelan di Dukuh Kadireso. Pada pengabdian ini, penulis berfokus pada kurangnya apresiasi pada warisan budaya dan kembali melakukan penyuluhan dengan metode pembelajaran langsung: teknik tiap ricikan, membaca notasi, dan praktik bersama. Materi yang diberikan diharapkan dapat membantu konsistensi kelompok gamelan ini untuk dapat beraktivitas secara mandiri. Hasil dari pengabdian ini adalah tercapainya penguasaan materi pada Gangsaran dan Lancaran "Ayo Kanca Nabuh Gamelan" serta terbentuknya komunitas diskusi kesenian di Karang Taruna Dukuh Kadireso.
\end{abstract}

Kata kunci: gamelan, notasi, ricikan, warisan budaya

\title{
Gamelan Art Workshop in Kadireso Village
}

\begin{abstract}
The writer is exposed to the community of Kadireso village started from an undergraduate field program, in which the writer met and started a gamelan (traditional Javanese music instrument) group. In this opportunity, the writer focuses in the community's lack of appreciation for the cultural heritage and reintroduces the gamelan workshop through an intensive teaching sessions: technique in each ricikan (stanza), reading music notes, and communal practices. The material given are hoped to be able to lead them into consistency and to engage in the activity independently. Results of this workshop shows that the group is now able to master the beginner drill of Gangsaran and Lancaran: "Ayo KancaNabuh Gamelan" and is able to solidify the arts discussion community in Kadireso village youth community.
\end{abstract}

Keyword: gamelan, music notes, ricikan, cultural heritage 


\section{PENDAHULUAN}

Kelompok gamelan di Dukuh Kadireso baru terbentuk sekitar tahun 2008 di rumah Bapak Suyadi - Kepala Dukuh setempat. Kelompok ini berdiri tepatnya pasca pelaksanaan salah satu program KKN Institut Seni Indonesia (ISI) Yogyakarta Angkatan XXVIII Tahun 2007/2008 di pedukuhan tersebut selama tiga bulan. Pada saat pelaksanaan KKN tersebut, penyuluh merupakan mahasiswa penggagas dan pelaksana program apresiasi musik tradisi latihan menabuh gamelan untuk orang tua serta anak-anak hingga pementasan. Saat itu penyuluh berinisiatif untuk menghidupkan kembali warisan gamelan yang diperkirakan telah ada sejak lebih dari setengah abad lalu. Kondisi gamelan pada saat itu - tahun 2007 - dalam keaadaan sangat tidak terawat karena memang sudah cukup lama dibiarkan tersimpan dalam gudang. Program KKN saat itulah yang menjadi cikal bakal terbentuknya kelompok gamelan ini.

Pada masa itu, masyarakat Kadireso khususnya di bagian utara (ring lor) menyambut bahagia program tersebut, bahkan ditindaklanjuti hingga membentuk kepengurusan kelompok gamelan berapa saat setelah program KKN berakhir. Namun, sepuluh tahun berjalan situasinya kini sudah berbeda. Kelompok gamelan di Dukuh Kadireso tersebut telah senyap tak bergema. Tidak ada aktivitas latihan lagi. Gamelan kembali disimpan di dalam gudang sebagaimana kondisi semula. Sejak dibentuk kepengurusan di tahun 2008, kelompok gamelan ini ternyata memang tidak bertahan lama. Berdasarkan observasi lapangan dan wawancara penyuluh pada tanggal 2 Maret 2019 dengan Kepala Dukuh Kadireso, dapat disimpulkan bahwa kondisi tersebut disebabkan karena banyaknya hambatan internal yang belum dapat diidentifikasi dengan jelas dan sampai saat ini cenderung dibiarkan begitu saja.

Setelah terjun dan melihat situasi terkini di lapangan, penyuluh menggarisbawahi bahwa permasalahan mendasar yang dihadapi kelompok ini berpangkal pada minimnya minat masyarakat setempat terhadap kesenian gamelan. Jika permasalahan tersebut dijabarkan maka secara garis besar akan berhubungan dengan tiga hal. Pertama, belum adanya orientasi yang mendalam tentang pentingnya melestarikan kesenian tradisi sebagai kekuatan gerakan budaya. Padahal kebesaran gamelan menurut Hastanto (2009:1) dikarenakan adanya kerumitan (sophesticated), keindahan (aestetic), keunikan (exotic), dan virtuositas para pemainnya di dalam menyajikan gending-gending (pieces).

Kedua, belum adanya kesadaran apresiasi yang mendasar tentang keindahan gamelan sehingga cenderung melihat keberadaan gamelan sebagai benda mati yang tidak begitu berharga. Seni Indonesia memang tengah dalam situasi yang kurang berdaya karena hidup yang dipacu dalam ketatnya ruang efisiensi sehingga seni mulai kehilangan maknanya dan memengaruhi lahirnya kedangkalan apresiasi (Sachari, 2002:63-64). Ketiga, belum adanya pelatih yang secara rutin memberikan bimbingan teratur dengan target capaian yang terukur.

Penyuluh menawarkan solusi penyuluhan seni di lokasi tersebut dengan tiga konsep materit: (1) membangun orientasi minat berkesnian gamelan, (2) praktik latihan dan penghayatan menabuh gamelan, dan (3) 
pengembangan wacana program pelatihan reguler secara mandiri.

Tujuan penyuluhan seni ini adalah untuk menumbuh-kembangkang minat masyarakat Dukuh Kadireso - khususnya generasi muda - terhadap kesenian gamelan dengan mendasarkan pemahaman akan pentingnya melestarikan kesenian tradisi di tengah masifnya ekspansi kebudayaan dunia yang tak kenal batas saat ini. Program penyuluhan ini secara implisit juga memuat orientasi pembentukan kemitraan yang berkesinambungan melalui berbagai bentuk pengembangan implementasi dan kreasi di kemudian hari.

Supanggah juga menarik terkait masalah tersebut adalah mengenai konsep gamelan yang mulur mungkret. Konsep ini dijelaskan Supanggah (2009:126) sebagai sikap inkonsistensi terhadap aturan, yang di sisi lain justru dapat menjadi petunjuk adanya sikap toleransi dan kreativitas dalam karawitan Jawa. Di sisi lain penyuluhan seni ini sekaligus juga akan memberikan stimulasi kepada masyarakat Kadireso untuk mengembangkan ragam peminatan seni, bukan hanya gamelan namun juga terhadap bidang seni yang lain secara umum.

Bagi Dosen, manfaat dari program penyuluhan ini tentu akan menjadi stimulasi konkrit untuk semakin meningkatkan kepedulian dan kepekaan terhadap perkembangan kehidupan seni di lingkungan sekitar. Bagaimana kompetensi yang dimiliki Dosen dapat selalu ditingkatkan dan sekaligus didedikasikan untuk terjun langsung berkontribusi bagi pengembangan potensi kesenian yang ada di masyarakat secara luas. Di sisi lain, melalui program penyuluhan seni ini mitra akan mendapatkan sentuhan intelektual yang mendasar tentang bagaimana membangun kesadaran apresiasi seni sehingga pelesetarian seni tradisi $\mathrm{di}$ daerahnya dapat diwujudkan secara berkesinambungan. Sedangkan bagi Pemerintah Daerah, program penyuluhan seni ini tentu dapat menjadi realisasi dari misi pemerataan pembangunan daerahnya melalui jalur kesenian sehingga ke depan dapat memperkaya potensi kearifan lokal.

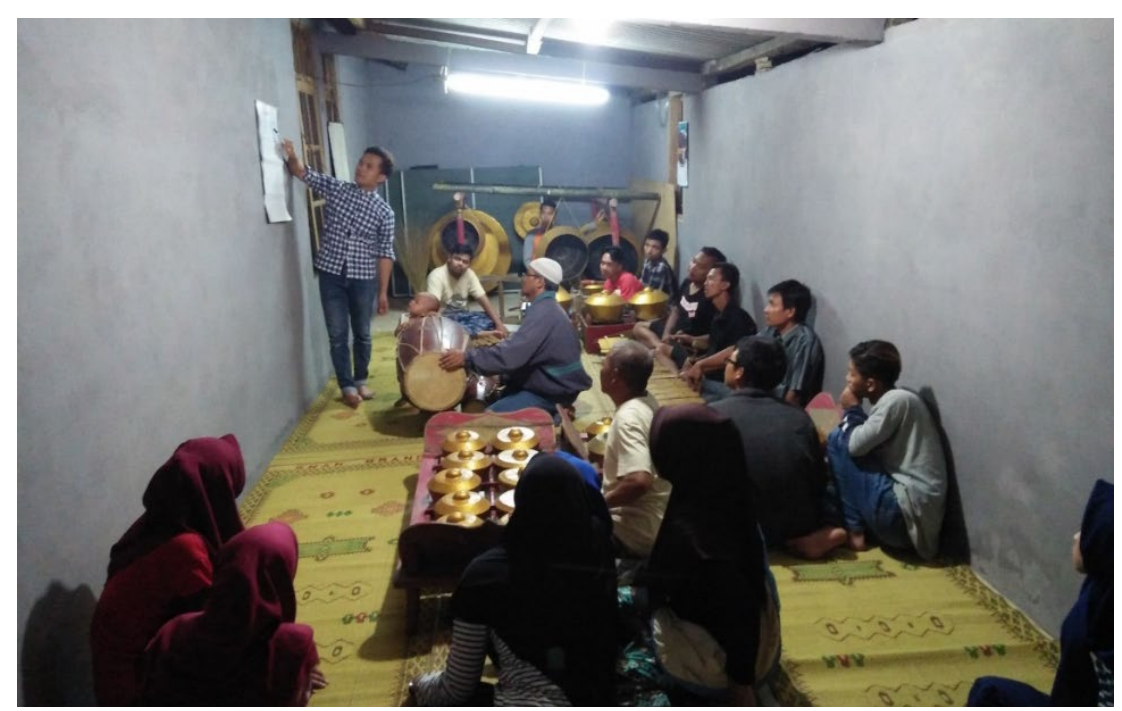

Gambar 1 Workshop Gamelan DukuhKadireso 


\section{METODE PENGABDIAN}

Khalayak yang menjadi sasaran program penyuluhan seni ini adalah warga Dukuh Kadireso, khususnya yang berdomisili di wilayah utara (ring lor). Dalam realisasinya, jumlah peserta yang aktif mengikuti program penyuluhan ini sebanyak 16 orang. Semula direncanakan akan diikuti oleh bapak-bapak dan pemuda Kadireso, namun dalam kenyataannya justru didominasi oleh pemuda dan pelajar yang sangat antusias mengikuti program penyuluhan seni ini.

Kegiatan ini dilaksanakan seluruhnya di rumah bapak Dukuh Kadireso yang berada di wilayah utara (ring lor). Tempat yang digunakan sebatas memanfaatkan garasi kendaraan yang tidak begitu luas namun memadai untuk proses penyuluhan.

Tabel 1 RincianKegiatanPenyuluhan

\begin{tabular}{|c|l|c|l|}
\hline Tatap Muka & Hari - & Waktu & Materi \\
\hline 1 & 23 Maret 2019 & $19.30-21.00$ & $\begin{array}{l}\text { Introduksi Penyuluhan Seni: } \\
\text { Diskusi Seputar Minat Seni }\end{array}$ \\
\hline 2 & 28 Maret 2019 & $19.30-21.30$ & Mengenal Ricikan Gamelan \\
\hline 3 & 2 April 2019 & $19.30-21.30$ & Praktik Menabuh Gangsaran \\
\hline 4 & 6 April 2019 & $19.30-21.30$ & Praktik Menabuh Gangsaran \\
\hline 5 & 9 April 2019 & $19.30-21.30$ & Praktik Nembang \\
\hline 6 & 13 April 2019 & $19.30-21.30$ & Praktik Nembang \\
\hline 7 & 18 April 2019 & $19.30-21.30$ & Praktik Nembang \\
\hline 8 & 22 April 2019 & $19.30-21.30$ & Praktik Menabuh Lancaran \\
\hline 9 & 23 April 2019 & $20.00-22.00$ & Praktik Menabuh Lancaran \\
\hline 10 & 27 April 2019 & $20.00-22.00$ & Praktik Menabuh Lancaran \\
\hline 11 & 1 Mei 2019 & $20.00-22.00$ & Praktik Menabuh Lancaran \\
\hline 12 & 2 Mei 2019 & $20.00-22.00$ & Evaluasi Kegiatan dan Penutupan \\
\hline & & & \\
\hline
\end{tabular}

Berkenaan dengan sasaran penyuluhan seni yang hampir semuanya masih dasar dan pemula, maka materi penyuluhan seni penyuluh susun mulai dari langsaran, belajar nembang, dan diakhiri dengan mencoba menabuh lancaran. Pada lancaran ini, penyuluh memilihkan materi lagu dolanan "Ayo Konco Nabuh Gamelan” yang secara eksplisit liriknya berhubungan erat dengan bagaimana seharusnya kita masyarakat Jawa dapat berperan aktif dalam melestarikan kesenian gamelan. Sepertidikutipdari Epperson, "the modality of music is auditory", materigarapmusik yang paling mendasardanmutlakadalahbunyi (1967:201).

Metode yang penyuluh gunakan untuk memberikan materi penyuluhan ini adalah memberikan contoh teknik permainan tiap 
ricikan, membaca notasi, praktek individu, belajar saling mendengarkan, dan terakhir praktek bersama.

\section{HASIL DAN PEMBAHASAN}

Kendala utama yang penyuluh hadapi dalam pelaksanaan kegiatan penyuluhan ini pertama berkaitan dengan kondisi gamelan yang sebenarnya sudah tidak layak. Gamelan ini memang sudah cukup lama tidak aktif digunakan. Terakhir digunakan adalah untuk program KKN ISI Yogyakarta tahun 2007. Laras gamelan ini ternyata sudah cukup blero dan beberapa ricikan sudah rapuh rancakannya, bahkan ada yang akhirnya patah setelah berakhirnya program penyuluhan ini. Kendala kedua, berkaitan dengan beberapa peserta yang tidak dapat rutin mengikuti penyuluhan seni ini karena bersamaan dengan jadwal bergilir dari pekerjaan para karyawan. Kendala terakhir, belum adanya pelatih yang akan melanjutkan program belajar ke depan. Kelompok yang sudah terbentuk ini menginginkan agar dapat memiliki pelatih rutin yang dapat mendampingi secara reguler sehingga akan lebih terarah

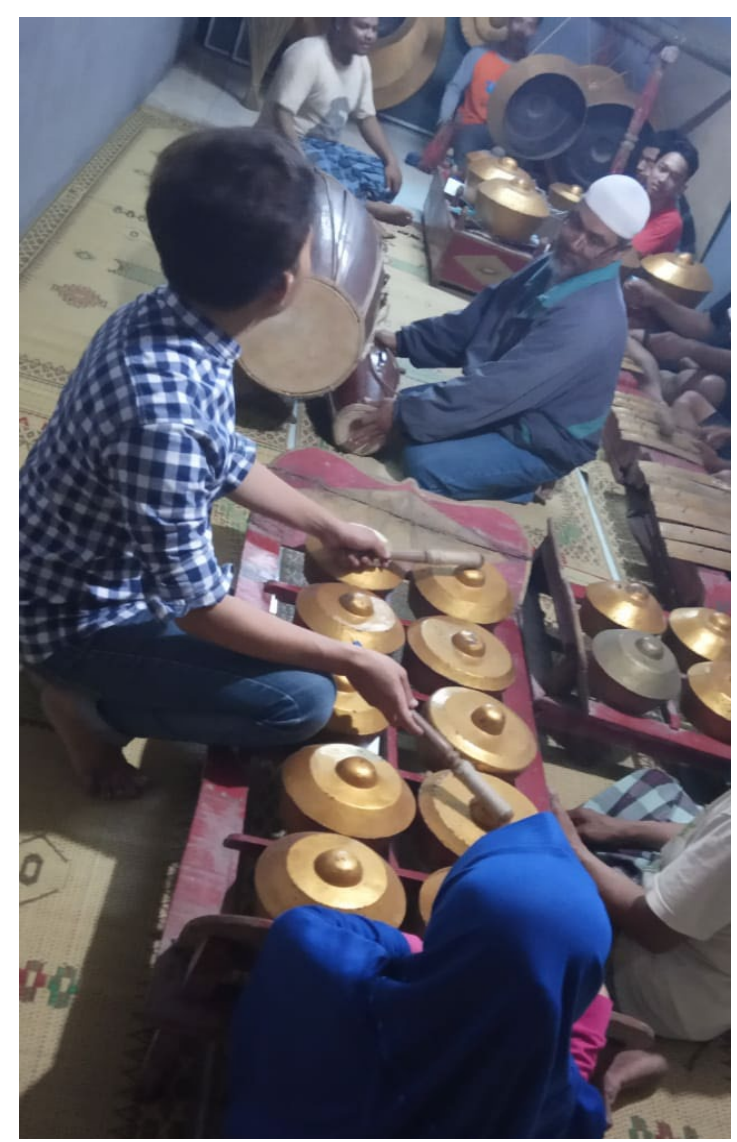

Gambar 2 Proses Kegiatan Penyuluhan 


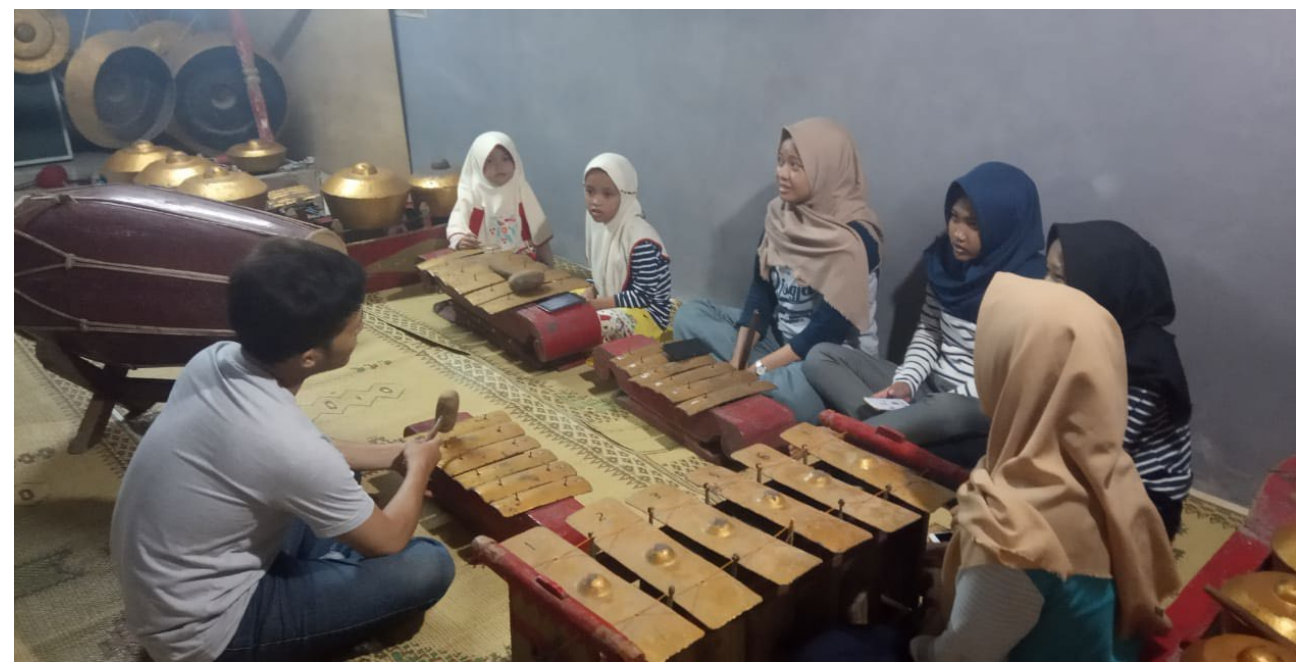

Gambar 3 Proses Latihan Nembang

Program penyuluhan seni ini telah menghasilkan tiga pencapaian penting, yaitu (1) terbukanya minat berkesenian gamelan di Dukuh Kadireso wilayah utara; (2) peserta penyuluhan dapat mengusai materi penyuluhan dengan baik - Gangsaran dan Lancaran "Ayo Kanca Nabuh Gamelan”; dan (3) terbentuknya komunitas diskusi kesenian di Karang Taruna Dukuh Kadireso wilayah utara.

\section{SIMPULAN}

Kegiatan penyuluhan seni di Dukuh Kadireso, Desa Triwidadi, Kecamatan Pajangan, Bantul ini secara umum dapat dilaksanakan sesuai dengan konsep dan target yang ditetapkan. Apresiasi seluruh peserta penyuluhan memperlihatkan keseriusan yang baik. Meskipun ada sedikit pergeseran segmentasi peserta karena dalam pelaksanaannya ternyata lebih didominasi para pemuda-pemudi Kadireso, namun dari awal pertemuan hingga penutupan seluruh agenda penyuluhan seni ini mendapatkan perhatian yang cukup antusias dan positif.
Tujuan dari penyuluhan seni ini juga dapat tercapai maksimal dengan penguasaan materi pelatihan yang lengkap.

Di sisi lain, pencapaian yang penting di luar pengusaan materi penyuluhan seni ini adalah keterkaitan implisit dengan program Pemerintah Provinsi DIY yang telah memilih Desa Triwidadi sebagai salah satu Desa Budaya sejak tahun 1994. Melalui program penyuluhan seni di Kadireso pada tahun ini Kepala Desa sangat merespon positif dan akan memperhatikan rintisan kelompok kesenian gamelan di Kadireso yang baru dibangun ini sebagai bagian dari elemen pengembangan Desa Budaya. Pemberdayaannya ke depan akan diupayakan untuk dapat memperoleh bimbingan dan pemantauan dari kelompok kesenian gamelan lain di Desa Triwidadi yang sudah berjalan reguler

\section{SARAN}

Berdasar pada capaian dan kendala yang dihadapi, maka untuk pengembangan 
dan perbaikan ke depan penyuluh dapat memberikan beberapa saran antara lain (1) Pemerintah Desa Triwidadi sebaiknya mulai memberikan perhatian khusus bagi kelompok gamelan pemuda yang sedang mulai dibentuk ini; (2) Pemerintah Desa Triwidadi dapat memberikan jalan keluar terkait dengan kondisi gamelan yang sedang memerlukan perbaikan serius; dan (3) Bagi Kepala Dukuh Kadireso, hendaknya selalu memotivasi kelompok gamelan pemuda di Kadireso ini dapat memiliki agenda latihan dan program rutin. Bagi para peserta penyuluhan, hendaknya dapat meneruskan capaian saat ini dengan terus menjaga keberadaan komunitas kesenian ini.

\section{UCAPAN TERIMA KASIH}

Penulis mengucapkan terima kasih kepada Lembaga Pengabdian kepada
Masyarakat Institut Seni Indonesia Yogyakarta yang telah memberi dukungan terhadap keberhasilan pengabdian ini.

\section{DAFTAR PUSTAKA}

Hastanto, S. (2009). Konsep Pathet dalam Karawitan Jawa. Surakarta: Program Pascasarjana Bekerja Sama dengan ISI Press.

Sachari, A. (2002). Estetika: Makna, Simbol dan Budaya, Bandung: ITB.

Supanggah, R. (2009). Bothèkan Karawitan II: Garap. Surakarta: Program Pascasarjana Bekerja Sama dengan ISI Press.

Epperson, G. (1967). The Musical Symbol: A Study of the Philosophic Theory of Music. Iowa, USA: The Iowa State University Press 